\title{
Rapid Inactivation of SARS-CoV-2 by Silicon Nitride, Copper, and Aluminum Nitride
}

Giuseppe Pezzotti, Ph.D. (Sci), Ph.D. (Eng), Ph.D. (Med), ${ }^{*}$ Eriko Ohgitani, Ph.D., Masaharu ShinYa, Ph.D., Tetsuya Adachi, D.M.D. Ph.D., Elia Marin, Ph.D., Francesco Boschetto, Ph.D., Wenliang Zhu, Ph.D., and Osam Mazda, M.D. Ph.D.*

\begin{abstract}
$\underline{\text { Abstract }}$
Introduction

Viral disease spread by contaminated commonly touched surfaces is a global concern. Silicon nitride, an industrial ceramic that is also used as an implant in spine surgery, has known antibacterial activity. The mechanism of antibacterial action relates to the hydrolytic release of surface disinfectants. It is hypothesized that silicon nitride can also inactivate the coronavirus SARS-CoV-2.
\end{abstract}

\section{Methods}

SARS-CoV-2 virions were exposed to $15 \mathrm{wt}$ \% aqueous suspensions of silicon nitride, aluminum nitride, and copper particles. The virus was titrated by the TCD 50 method using VeroE6/TMPRSS2 cells, while viral RNA was evaluated by real-time RT-PCR. Immunostaining and Raman spectroscopy were used as additional probes to investigate the cellular responses to virions exposed to the respective materials.

\section{Results}

All three tested materials showed $>99 \%$ viral inactivation at one and ten minutes of exposure. Degradation of viral RNA was also observed with all materials. Immunofluorescence testing showed that silicon nitride-treated virus failed to infect VeroE6/TMPRSS2 cells without damaging them. In contrast, the copper-treated virus suspension severely damaged the cells due to copper ion toxicity. Raman spectroscopy indicated differential biochemical cellular changes due to infection and metal toxicity for two of the three materials tested.

\section{Conclusions}

Silicon nitride successfully inactivated the SARS-CoV-2 in this study. The mechanism of action was the hydrolysis-mediated surface release of nitrogen-containing disinfectants. Both aluminum nitride and copper were also effective in the inactivation of the virus. However, while the former compound affected the cells, the latter compound had a cytopathic effect. Further studies are needed to validate these findings and investigate whether silicon nitride can be incorporated into personal protective equipment and commonly touched surfaces, as a strategy to discourage viral persistence and disease spread.

*Corresponding Authors: Professor Giuseppe Pezzotti, Ceramic Physics Laboratory, Materials Science Division Kyoto Institute of Technology, Matsugasaki, Sakyo-Ku, Kyoto 606-8585, Japan. Email: pezzotti@kit.ac.jp; and, Professor Osam Mazda, Department of Immunology, Graduate School of Medical Science, Kyoto Prefectural University of Medicine, Kamigyo-ku, 465 Kajiicho, Kyoto 602-8566, Japan. Email: mazda@ koto.kpu-m.ac.jp See note at the end of the paper for coauthor affiliations. 


\section{Introduction}

The novel coronavirus, SARS-CoV-2, has led to a worldwide pandemic and raised interest in the surface-mediated transmission of viral diseases [1-3]. Respiratory aerosols and droplets, and contaminated surfaces facilitate viral spread from person to person leading to recommendations of social distancing, wearing of masks, hand-washing, and regular surface disinfection. Data suggest that the SARS-CoV-2 virus can remain viable on copper, plastic, steel, and cardboard surfaces for 4-72 hours after contact, and up to 7-days on surgical masks [4]. Viral persistence on these and other materials presents a risk for the social and nosocomial propagation of COVID-19, the disease caused by SARS-CoV-2. Current viral inactivation methods include the surface application of chemicals, such as a combination of ethanol with hydrogen peroxide or sodium hypochlorite [2]. Irradiation of surfaces with ultraviolet light is another virus disinfection strategy [5]. These and other proposed antiviral methodologies are ultimately limited by their toxicity to human cells [6,7]. As a practical solution, surfaces that are safe for human contact and capable of spontaneously inactivating viruses are desirable to control the spread of viral diseases.

Silicon nitride $\left(\mathrm{Si}_{3} \mathrm{~N}_{4}\right)$ is a non-oxide ceramic that has been used in many industries since the 1950s. A formulation of $\mathrm{Si}_{3} \mathrm{~N}_{4}$ is FDA-cleared for use as an intervertebral spinal spacer in cervical and lumbar spine fusion surgery, with proven long-term safety, efficacy, and biocompatibility. Clinical data for $\mathrm{Si}_{3} \mathrm{~N}_{4}$ implants compare favorably with other spine biomaterials, such as allograft, titanium, and polyetheretherketone [8-13]. A curious finding is that $\mathrm{Si}_{3} \mathrm{~N}_{4}$ implants have a lower incidence of bacterial infection (i.e., less than $0.006 \%$ ) when compared to other implant materials $\left(2.7 \%\right.$ to $18 \%$ ) [14]. This property reflects the complex surface biochemistry of $\mathrm{Si}_{3} \mathrm{~N}_{4}$ that elutes minute amounts of nitrogen, which is converted to ammonia, ammonium, and other reactive nitrogen species (RNS) that inhibit bacteria [15]. A recent investigation also found that viral exposure to sintered $\mathrm{Si}_{3} \mathrm{~N}_{4}$ powders in aqueous suspension inactivated $\mathrm{H} 1 \mathrm{~N} 1$ (Influenza A/Puerto Rico/8/1934), Feline calicivirus, and Enterovirus (EV-A71) [16]. Based on these findings, it is hypothesized that $\mathrm{Si}_{3} \mathrm{~N}_{4}$ may be able to inactivate $\mathrm{SARS}-\mathrm{CoV}-2$.

The present study compared the effects of exposing SARS-CoV-2 to aqueous suspensions of $\mathrm{Si}_{3} \mathrm{~N}_{4}$ and aluminum nitride (AlN) particles and two controls, (i.e., a suspension of copper ( $\mathrm{Cu}$ ) particles (positive control) and a sham treatment (negative control)). $\mathrm{Cu}$ was chosen as a positive control because of its well-known ability to inactivate a variety of microbes, including viruses [17]. AlN was included in the testing because, like $\mathrm{Si}_{3} \mathrm{~N}_{4}$, it is a nitrogen-based compound whose surface hydrolysis in aqueous solution leads to the elution of ammonia, with an attendant increase in $\mathrm{pH}$. Since comparable antiviral and antibacterial phenomena are believed to be operative for all nitridebased compounds, AlN was used to provide additional insight into the antipathogenic mechanisms of nitrogen-containing inorganic materials $[18,19]$.

\section{Materials and Methods}

\section{Preparation of Test Materials}

$\mathrm{Si}_{3} \mathrm{~N}_{4}, \mathrm{Cu}$, and $\mathrm{AlN}$ powders were acquired from commercial sources (SINTX Technologies, Inc., Salt Lake City, UT USA, FUJIFILM Wako Pure Chemical Corporation, Osaka, Japan, and Tokuyama Co., Yamaguchi, Japan, respectively). $\mathrm{Si}_{3} \mathrm{~N}_{4}$ powder (nominal composition of 90 wt.\% $\mathrm{Si}_{3} \mathrm{~N}_{4}, 6$ wt.\% $\mathrm{Y}_{2} \mathrm{O}_{3}$, and 4 wt.\% $\mathrm{Al}_{2} \mathrm{O}_{3}$ ) [20] was prepared by aqueous mixing and spray-drying 
of the inorganic constituents, followed by sintering of the spray-dried granules $\left(\sim 1700^{\circ} \mathrm{C}\right.$ for $\sim 3$ h), hot-isostatic pressing $\left(\sim 1600^{\circ} \mathrm{C}, 2 \mathrm{~h}, 140 \mathrm{MPa}\right.$ in $\left.\mathrm{N}_{2}\right)$, aqueous-based comminution, and freezedrying. The resulting powder had an average particle size of $0.8 \pm 1.0 \mu \mathrm{m}$. As-received $\mathrm{Cu}$ powder (USP grade $99.5 \%$ purity) granules were comminuted to achieve a particle size comparable to the $\mathrm{Si}_{3} \mathrm{~N}_{4}$. AlN powder had an average particle size of $1.2 \pm 0.6 \mu \mathrm{m}$ as received, which was comparable to $\mathrm{Si}_{3} \mathrm{~N}_{4}$.

\section{Cells and Virus}

VeroE6/TMPRSS2 cells (Japanese Collection of Research Biosources Cell Bank, National Institute of Biomedical Innovation, Osaka, Japan) were used in the viral assays [21]. Cells were grown in Dulbecco's modified Eagle's minimum essential medium (DMEM) (Nissui Pharmaceutical Co. Ltd., Tokyo, Japan) supplemented with G418 disulfate (1 mg/ml), penicillin (100 units/mL), streptomycin $(100 \mu \mathrm{g} / \mathrm{mL}), 5 \%$ fetal bovine serum, and maintained at $37^{\circ} \mathrm{C}$ in a $5 \% \mathrm{CO}_{2} / 95 \%$ in a humidified atmosphere. The SARS-CoV-2 (Japan/AI/I- 004/2020; Japan National Institute of Infectious Diseases, Tokyo, Japan) viral stock was propagated using VeroE6/TMPRSS2 cells at $37^{\circ} \mathrm{C}$ for 2 days.

\section{Viral infection}

Fifteen weight percent (15 wt.\%) of the $\mathrm{Si}_{3} \mathrm{~N}_{4}, \mathrm{Cu}$, and $\mathrm{AlN}$ powders were separately dispersed in $1 \mathrm{~mL}$ of PBS(-), followed by the addition of the viral suspension $\left(2 \times 10^{5}\right.$ median tissue culture infectious dose $\left(\mathrm{TCID}_{50}\right)$ in $20 \mu \mathrm{L}$ ). Due to the higher density of the $\mathrm{Cu}$ powder, its volumetric fraction was approximately one-third of the $\mathrm{Si}_{3} \mathrm{~N}_{4}$. Mixing was gently performed at room temperature for $1 \mathrm{~min}$ by slow manual rotation or for $10 \mathrm{~min}$ using a rotation machine. After exposure, the powders were pelleted by centrifugation (2400 RPM 2 mins) followed by filtration through a $0.22 \mu \mathrm{m}$ filter (Hawach Sterile PES Syringe Filter, HAWACH SCIENTIFIC CO., LTD., Xi'an, China). Supernatants were collected, aliquoted, and subjected to TCID 50 assays and real-time RTPCR.

\section{Titration of virus}

Experiments were performed in triplicate including sham-treated virus suspension that was not exposed to any powder. A confluent monolayer of VeroE6/TMPRSS2 cells in a 96-well plate was inoculated with $50 \mu \mathrm{L} /$ well of each virus suspension in a tenfold serial dilution with $0.5 \%$ FBS DMEM (i.e., maintenance medium). Viral adsorption at $37^{\circ} \mathrm{C}$ for $1 \mathrm{~h}$ was made with gently shaking every $10 \mathrm{~min}$. Afterward, $50 \mu \mathrm{L} /$ well of the maintenance medium was added. The plate was incubated at $37^{\circ} \mathrm{C}$ in a $5 \% \mathrm{CO}_{2} / 95 \%$ humidified atmosphere for 4 days. The cytopathic effect (CPE) of the infected cells was observed under a phase-contrast microscope. The cells were subsequently fixed by adding $10 \mu \mathrm{L} /$ well of glutaraldehyde followed by staining with $0.5 \%$ crystal violet. The TCID 50 was calculated according to the Reed-Muench method [22].

\section{Viral RNA Assay}

After exposure to the powders, $140 \mu \mathrm{L}$ of the supernatants were used for viral RNA extraction. RNA was also extracted from the surfaces of the centrifuged and filtered powders. RNA purification was performed by using a QIAamp Viral RNA Mini kit (QIAGEN, Germantown, MD, USA). An aliquot of $16 \mu \mathrm{L}$ of isolated RNA was reverse-transcribed using ReverTra Ace ${ }^{\circledR}$ qPCR RT Master Mix (Toyobo, Shiga, Japan). Quantitative real-time PCR was performed using a Step-One Plus Real-Time PCR system (Applied Biosystems, Foster City, CA, USA) and two sets of 
primers/probes specific for viral $\mathrm{N}$ gene.

Set 1: (forward primer, 5'-CACATTGGCACCCGCAATC-3'; reverse primer, 5'-GAGGAACGAGAAGAGGCTTG-3'; ; probe, 5'-(FAM) ACTTCCTCAAGGAACAACATTGCCA (BHQ) 3'); and Set 2: (forward primer, 5'-AAATTTTGGGGACCAGGAAC-3'; reverse primer, 5'-TGGCAGCTGTGTAGGTCAAC-3'’; probe, 5'-(FAM) ATGTCGCGCATTGGCATGGA (BHQ) 3').

Each $20 \mu \mathrm{L}$ reaction mixture contained $4 \mu \mathrm{L}$ of cDNA, 8.8 pmol of each primer, 2.4 pmol of the probe, and $10 \mu \mathrm{L}$ GoTaq Probe qPCR master mix (Promega, Madison, WI, USA). The amplification protocol consisted of 50 cycles of denaturation at $95^{\circ} \mathrm{C}$ for $3 \mathrm{~s}$ and annealing and extension at $60^{\circ} \mathrm{C}$ for $20 \mathrm{~s}$.

\section{Immunofluorescence}

Vero E6/TMPRSS2 cells on cover glass were inoculated with $200 \mu \mathrm{L}$ of virus supernatant. After viral adsorption at $37^{\circ} \mathrm{C}$ for $1 \mathrm{~h}$, the cells were incubated with the maintenance medium in a $\mathrm{CO}_{2}$ incubator for $7 \mathrm{~h}$. For the detection of infected cells, they were washed with TBS (20 mM Tris$\mathrm{HCl} \mathrm{pH} \mathrm{7.5,} 150 \mathrm{mM} \mathrm{NaCl}$ ) and fixed with 4\% PFA for $10 \mathrm{~min}$ at room temperature (RT) followed by membrane permeabilization with $0.1 \%$ Triton X in TBS for 5 min at RT. The cells were blocked with $2 \%$ skim milk in TBS for $60 \mathrm{~min}$ at RT and stained with anti-SARS Coronavirus envelope (Rabbit) antibody (Dilution =1:100) (ProSci Inc., Poway, CA, USA) for $60 \mathrm{~min}$ at RT. After washing with a buffer, cells were incubated with an Alexa 594 Goat Anti- Rabbit IgG (H+L) (1:500) (Thermo Fisher Scientific, Waltham, MA, USA) and Alexa 488 Phalloidin (1:50) (Thermo Fisher Scientific, Waltham, MA, USA) for $60 \mathrm{~min}$ at RT in the dark. ProLongTM Diamond Antifade Mountant with DAPI (Thermo Fisher Scientific) was used as a mounting medium. The staining was observed under a fluorescent microscope BZX710 (Keyence, Osaka, Japan). The total cells, Phalloidin-staining cells, and protein-expressing cells were counted using the Keyence BZ-X Analyzer.

\section{Raman Spectroscopy Assay}

Vero E6/TMPRSS2 cells were infected with $200 \mu \mathrm{L}$ of each virus suspension on glass sites. After viral adsorption at $37^{\circ} \mathrm{C}$ for $1 \mathrm{~h}$, the infected cells were incubated with the maintenance medium in a $\mathrm{CO}_{2}$ incubator for $4 \mathrm{~h}$ and fixed with $4 \%$ paraformaldehyde for $10 \mathrm{~min}$ at RT. After washing with distilled water twice, infected cells were air-dried and in situ analyzed using a highly sensitive Raman spectroscope (LabRAM HR800, Horiba/Jobin-Yvon, Kyoto, Japan) with a 20× optical lens. It operated in microscopic measurement mode with confocal imaging in two dimensions. A holographic notch filter within the optical circuit was used to efficiently achieve a spectral resolution of $1.5 \mathrm{~cm}^{-1}$ via a $532 \mathrm{~nm}$ excitation source operating at $10 \mathrm{~mW}$. Raman emissions were monitored using a single monochromator connected to an air-cooled charge-coupled device (CCD) detector (Andor DV420-OE322; $1024 \times 256$ pixels). The acquisition time was fixed at $10 \mathrm{~s}$. Thirty spectra were collected and averaged for each analysis time-point. Raman spectra were deconvoluted into Gaussian-Lorentzian sub-bands using commercially available software (LabSpec 4.02, Horiba/Jobin-Yvon, Kyoto, Japan).

\section{Statistical Analysis}

The Student's $t$-test determined statistical significance for $\mathrm{n}=3$ and at a $p$-value of 0.01 using Prism software (GraphPad, San Diego, CA USA). 


\section{Results}

\section{Median Tissue Culture Infection Dose}

$\mathrm{TCID}_{50}$ assay results for the $15 \mathrm{wt} . \% \mathrm{Si}_{3} \mathrm{~N}_{4}, \mathrm{Cu}$, and AlN powders are shown in Figure 1. Inactivation times of 1 and 10 mins are shown in Fig. 1(a) (b) and Fig. 1(c) (d), respectively. Relative to the negative control, all three powders were effective in inactivating SARS-CoV-2 virions $(>99 \%)$ for the two exposure times.

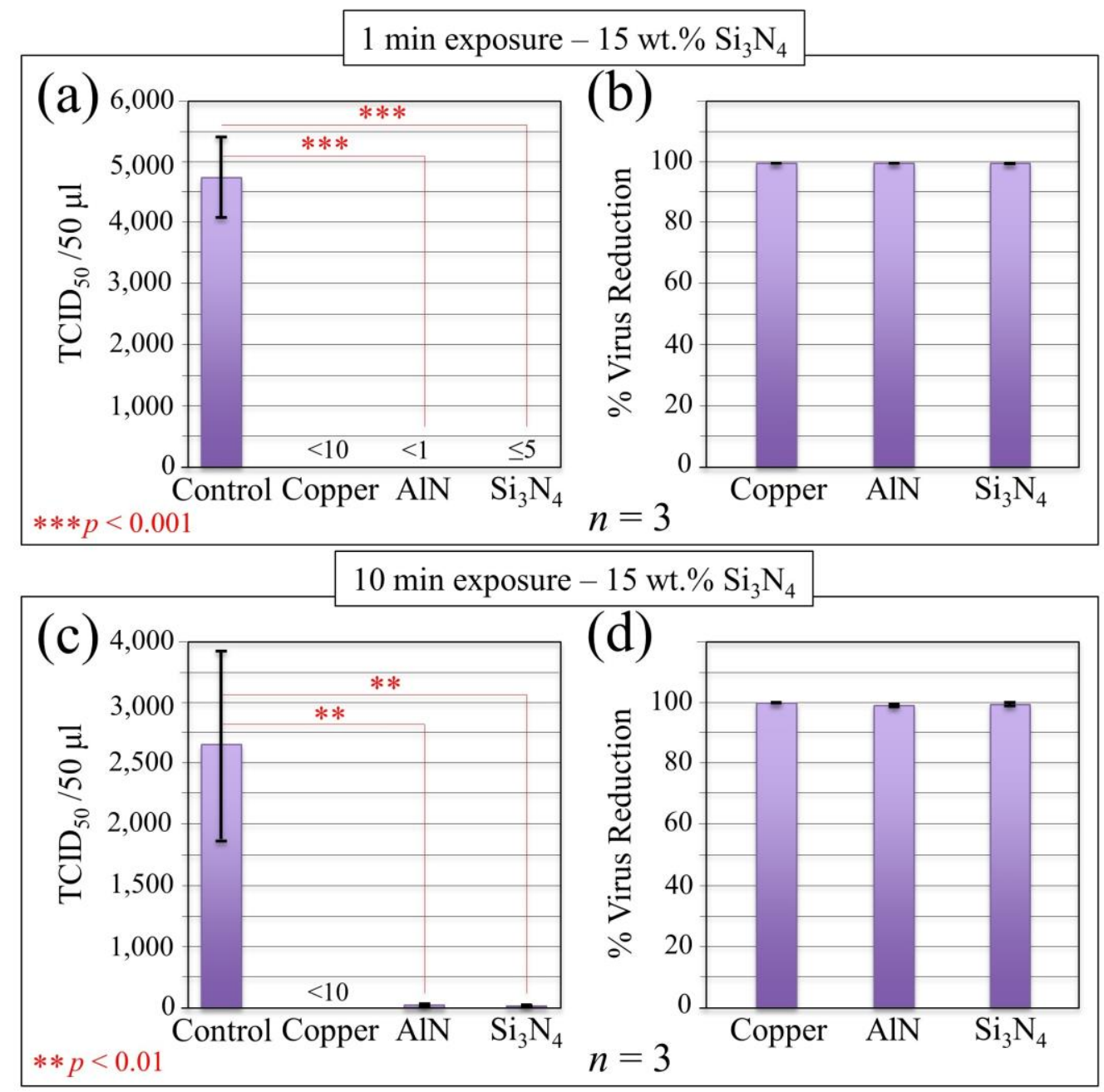

Figure 1. Inactivation of SARS-CoV-2 by nitride powders; virus suspensions were treated with $15 \mathrm{wt} . \% \mathrm{Cu}, \mathrm{AlN}$, and $\mathrm{Si}_{3} \mathrm{~N}_{4}$ powders in an aqueous medium at room temperature for $1-$ and $10-\mathrm{min}$. The control virus was treated identically without the addition of any powder. After light centrifugation and filtration, supernatants were subjected to $\mathrm{TCID}_{50}$ assay. The Reed-Muench method was used to determine the virus titers. $\mathrm{TCID}_{50} / 50 \mu \mathrm{L}(\mathrm{a}) /(\mathrm{b})$ and $\%$ reduction $(\mathrm{c}) /(\mathrm{d})$ are shown for virus inactivation times of 1 and 10 min, respectively. Statistics are given in the inset according to unpaired two-tailed Student's t-test $(n=3)$. 


\section{RNA Fragmentation}

To examine whether viral RNA was fragmented from exposure to the powders, RT-PCR tests were conducted on the viral $\mathrm{N}$ gene sequence. The results are shown in Fig. 2(a) (b) and (c) (d) for 1and 10-min exposures, respectively. Again, in comparison to the supernatant of the negative control that was not exposed to any powder, almost complete fragmentation of the RNA was observed for $\mathrm{Cu}$ while significant damage was caused by AlN and to a lesser extent by $\mathrm{Si}_{3} \mathrm{~N}_{4}$. After $10 \mathrm{~min}$ exposure to the powders, substantial cleavage of the RNA was seen for all three materials. While $\mathrm{Cu}$ still showed the most fragmentation, $\mathrm{Si}_{3} \mathrm{~N}_{4}$ demonstrated similar effectiveness, and AlN was essentially identical to the 1-min exposure condition.

Viral RNA was virtually undetectable for all three materials from the pelleted powders after $1 \mathrm{~min}$ of exposure ( $c f$. Fig. 2(a) (b)). This result suggests that the decrease of viral RNA in the supernatant was not because of adherence of the RNA to the powders, but rather due to degradation.
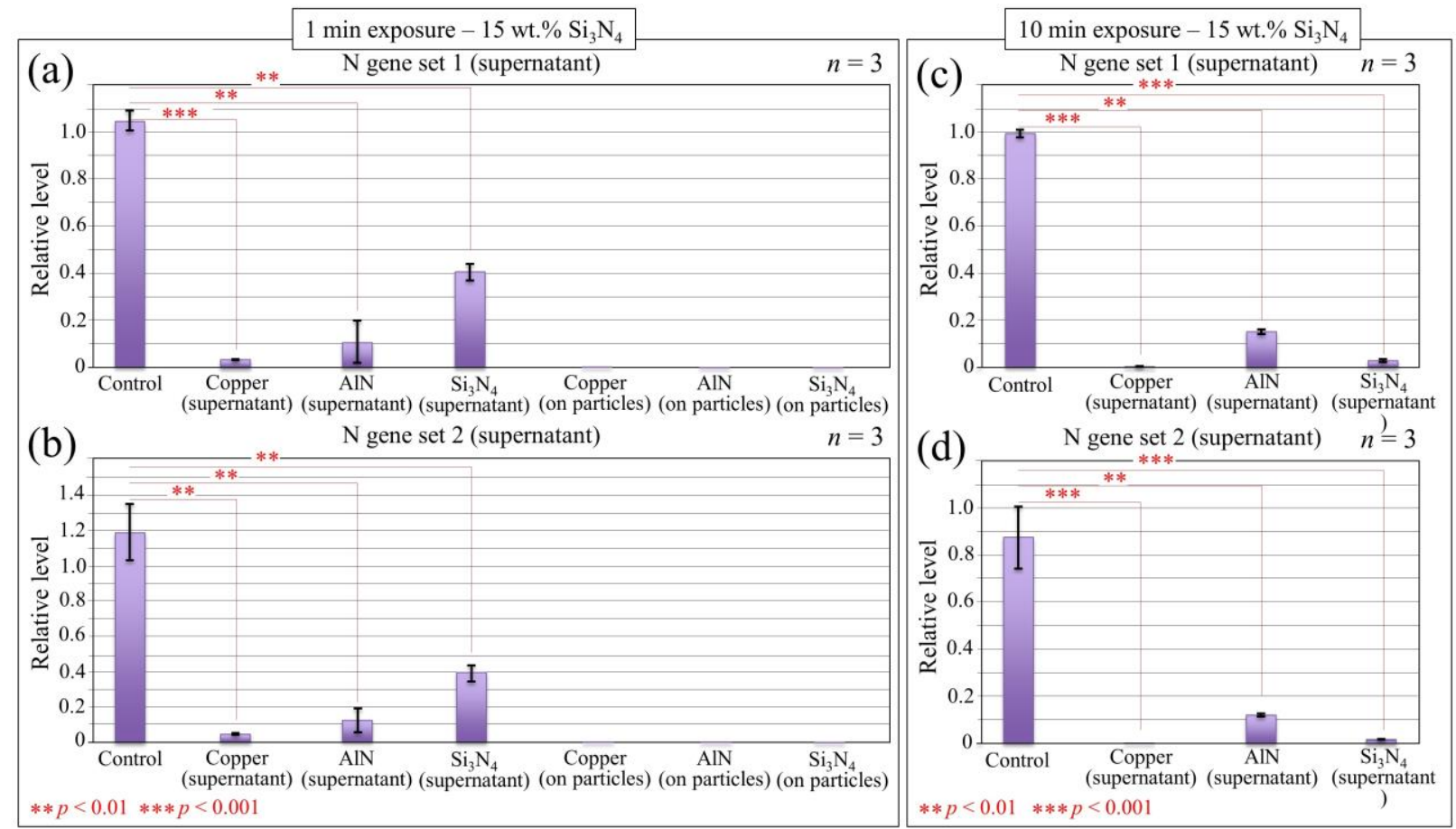

Figure 2. Viral RNA underwent severe degradation after exposure to copper or nitride particles. In (a) and (b), virus suspensions were exposed to $\mathrm{Cu}, \mathrm{AlN}$, and $\mathrm{Si}_{3} \mathrm{~N}_{4}$ powders for 1 min, and viral RNA in supernatants and on particles were evaluated using viral N gene "set 1" and "set 2" primers, respectively. Data collected on supernatants and pellet samples are given in comparison with the amount of viral $\mathrm{N}$ gene RNA in suspension that was left untreated. In (c) and (d), results of RT-PCR tests for supernatants after 10 min exposure of virus suspension to $\mathrm{Cu}, \mathrm{AlN}$, and $\mathrm{Si}_{3} \mathrm{~N}_{4}$ powders for viral $\mathrm{N}$ gene "set 1 " and "set 2 " primers are shown, respectively. Statistics are given in the inset according to unpaired two-tailed Student's $t$-test $(n=3)$.

\section{Immunofluorescence Testing}

Immunofluorescence imaging using anti-SARS coronavirus envelope antibody (red), Phalloidin that stains F-actin in viable cells (green), and DAPI for cell nuclear staining (blue) was then used to confirm the TCID 50 assay and gene fragmentation results. Figures 3(a) (d) show fluorescence 
micrographs representative of the VeroE6/TMPRSS2 cell populations that were inoculated with supernatants of (a) unexposed virions (i.e., negative control) and 10-min-exposed virions of (b) $\mathrm{Si}_{3} \mathrm{~N}_{4}$, (c) AlN, and (d) Cu. Figure 3(e) shows cells that were not inoculated with the virus (labeled as "sham-infected" cells. The red-fluorescent signals in the negative control (Fig. 3(a)) demonstrated that the virus had infected the cells and viral protein was synthesized. This contrasts with the sham-infected cells (Fig. 3(e)), which did not show any evidence of expression of the viral protein.
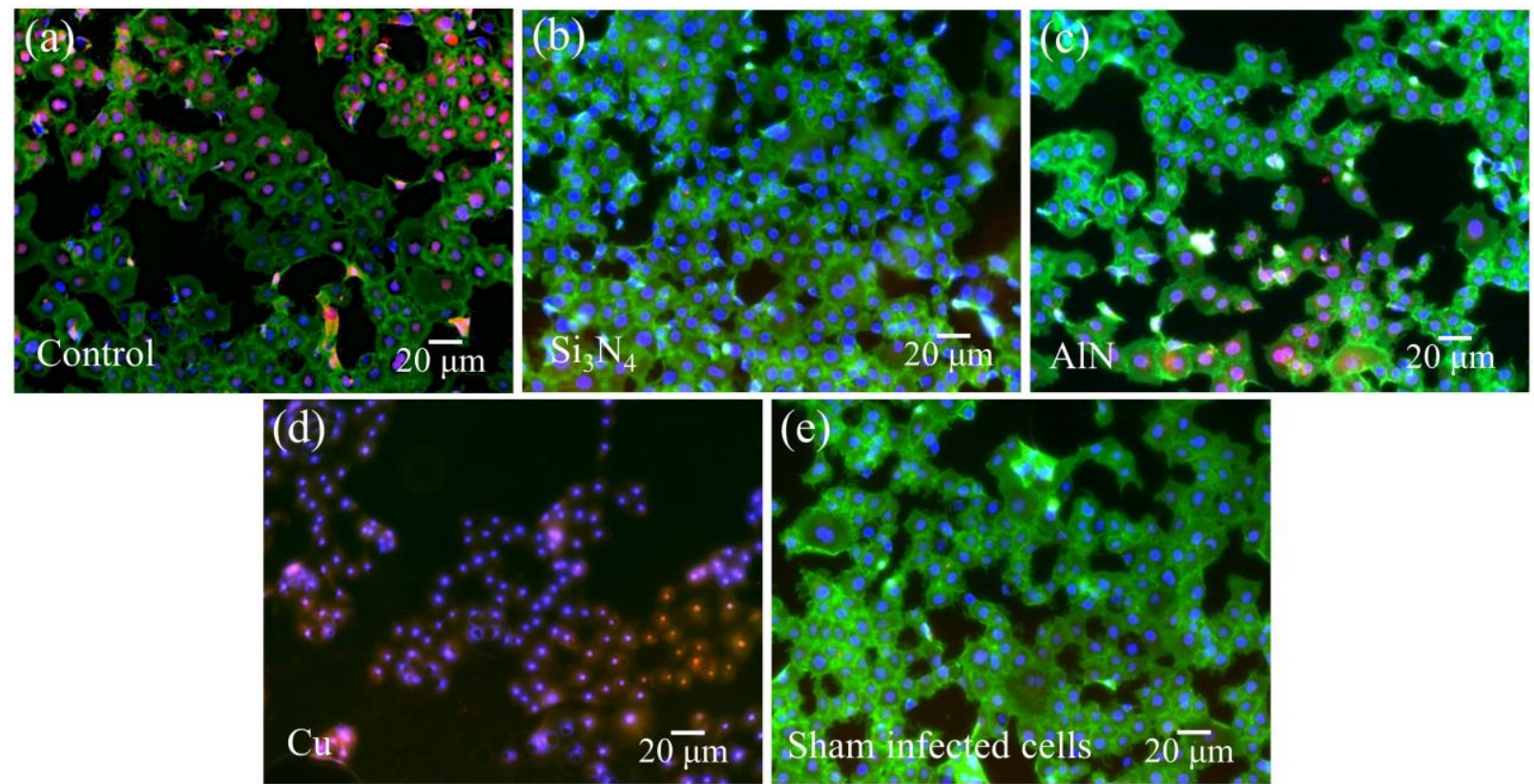

Figure $3 . \mathrm{Si}_{3} \mathrm{~N}_{4}$ suppressed virus infection without affecting cell viability, whereas $\mathrm{Cu}$ killed the cells. VeroE6/TMPRSS2 cells were inoculated with (a) unexposed virions, and virions 10-minexposed to (b) $\mathrm{Si}_{3} \mathrm{~N}_{4}$, (c) $\mathrm{AlN}$, and (d) $\mathrm{Cu}$, followed by culture for $7 \mathrm{~h}$. In (e), non-inoculated cells (labeled as "sham-infected" cells) were also prepared and imaged for comparison. After fixation, cells were stained with anti-SARS coronavirus envelope antibody (red), Phalloidin to visualize F-actin (green), and DAPI to stain nuclei (blue). Fluorescence micrographs are shown, which are representative of $n=3$ samples.

Remarkably, cells inoculated with supernatants from $\mathrm{Si}_{3} \mathrm{~N}_{4}$ and, to a lesser extent, from AlN demonstrated near-normal viability with few infections. Conversely, cells inoculated with the $\mathrm{Cu}$ supernatant were essentially dead as suggested by a complete lack of F-actin (Fig. 3(d)). This indicates that cell death did not result from viral infection but from toxic effects of intracellular free $\mathrm{Cu}$ ions [23]. Quantification of the fluorescent microscopic results from Figure 3 is provided in Figure 4, assuming that the Phalloidin-positive cells were viable and anti-SARS envelope antibody-stained cells were infected. These data demonstrate that about $35 \%$ of the viable VeroE6/TMPRSS2 cells from the negative control were infected, whereas only $2 \%$ and $8 \%$ of cells inoculated with supernatants from $\mathrm{Si}_{3} \mathrm{~N}_{4}$ and $\mathrm{AlN}$ were infected, respectively. 


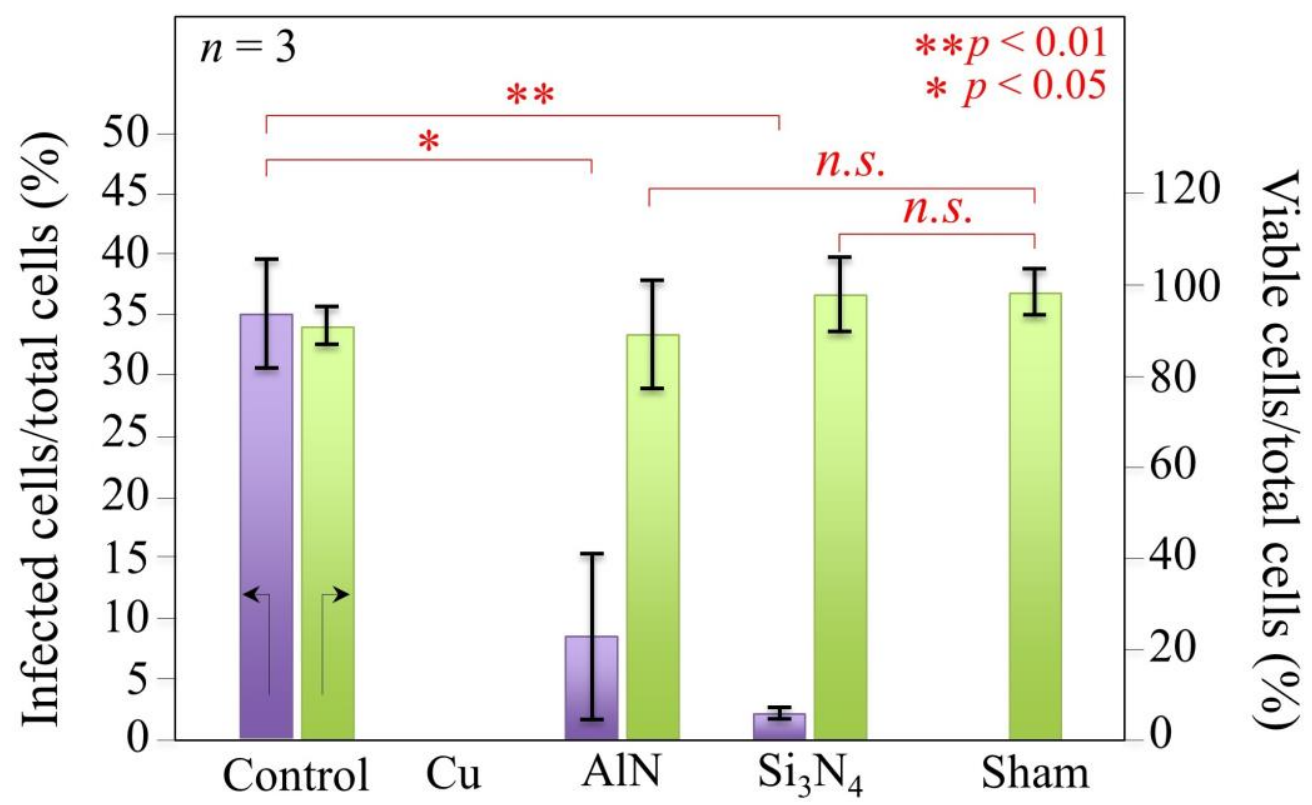

Figure 4. Fluorescently labeled and non-labeled cells were counted on fluorescence micrographs. Values were calculated as follows: \% infected cells/total cells $=$ (number of the cells stained with anti-SARS coronavirus envelope antibody) / (number of nuclei stained with DAPI) x 100; and, \% viable cells/total cells $=($ number of the cells stained with Phalloidin $) /($ number of nuclei stained with DAPI) x 100. Data are representative of $n=3$ samples. $*$ and $* *$ are $p<0.05$ and 0.01 , respectively, by unpaired two-tailed Student's $t$-test $(n=3) ; n . s .=$ nonsignificant

\section{Raman Spectroscopy}

Raman spectroscopy examined VeroE6/TMPRSS2 cells exposed to the various supernatants to assess biochemical cellular changes due to infection and ionic (i.e., $\mathrm{Cu}$ and $\mathrm{Al}$ ) toxicity. Figure 5 shows Raman spectra in the frequency range 700-900 $\mathrm{cm}^{-1}$ for (a) uninfected VeroE6/TMPRSS2 cells, and cells inoculated with supernatants containing virions exposed for 10 mins to (b) $\mathrm{Si}_{3} \mathrm{~N}_{4}$, (c) AlN, (d) $\mathrm{Cu}$ (positive control), and (e) no antiviral compounds (negative control). Of fundamental importance are the vibrational bands of ring breathing and $\mathrm{H}$-scissoring of the indole ring of tryptophan (at 756 and $875 \mathrm{~cm}^{-1}$ [24], labeled as $T_{1}$ and $T_{2}$, respectively). Tryptophan plays a vital role in protein synthesis and the generation of molecules for various immunological functions. Its stereoisomers serve to anchor proteins within the cell membrane [25] and its catabolites possess immunosuppressive functions [26]. The catabolism of tryptophan is triggered by a viral infection. This occurs via the enzymatic activity of indoleamine-2,3-dioxygenase (IDO) which protects the host cells from an over-reactive immune response. IDO reduces tryptophan to kynurenine and then to N'-formyl-kynurenine. An increase in IDO activity depletes tryptophan [27]. Consequently, the intensity of the tryptophan bands $\left(\mathrm{T}_{1}\right.$ and $\left.\mathrm{T}_{2}\right)$ is an indicator of these biochemical changes. Except for the $\mathrm{Cu}$ - treated sample, the data presented in Fig. 5(f) show an exponential decline in the combined tryptophan bands that correlates with the fraction of infected cells. (The chemical structure of N'-formyl-kynurenine is given in the inset for clarity.) The anomaly for copper provides further evidence of its toxicity. The VeroE6/TMPRSS2 cells consumed tryptophan to reduce $\mathrm{Cu}^{2+}$ and 
stabilize it as $\mathrm{Cu}^{+}[28]$.
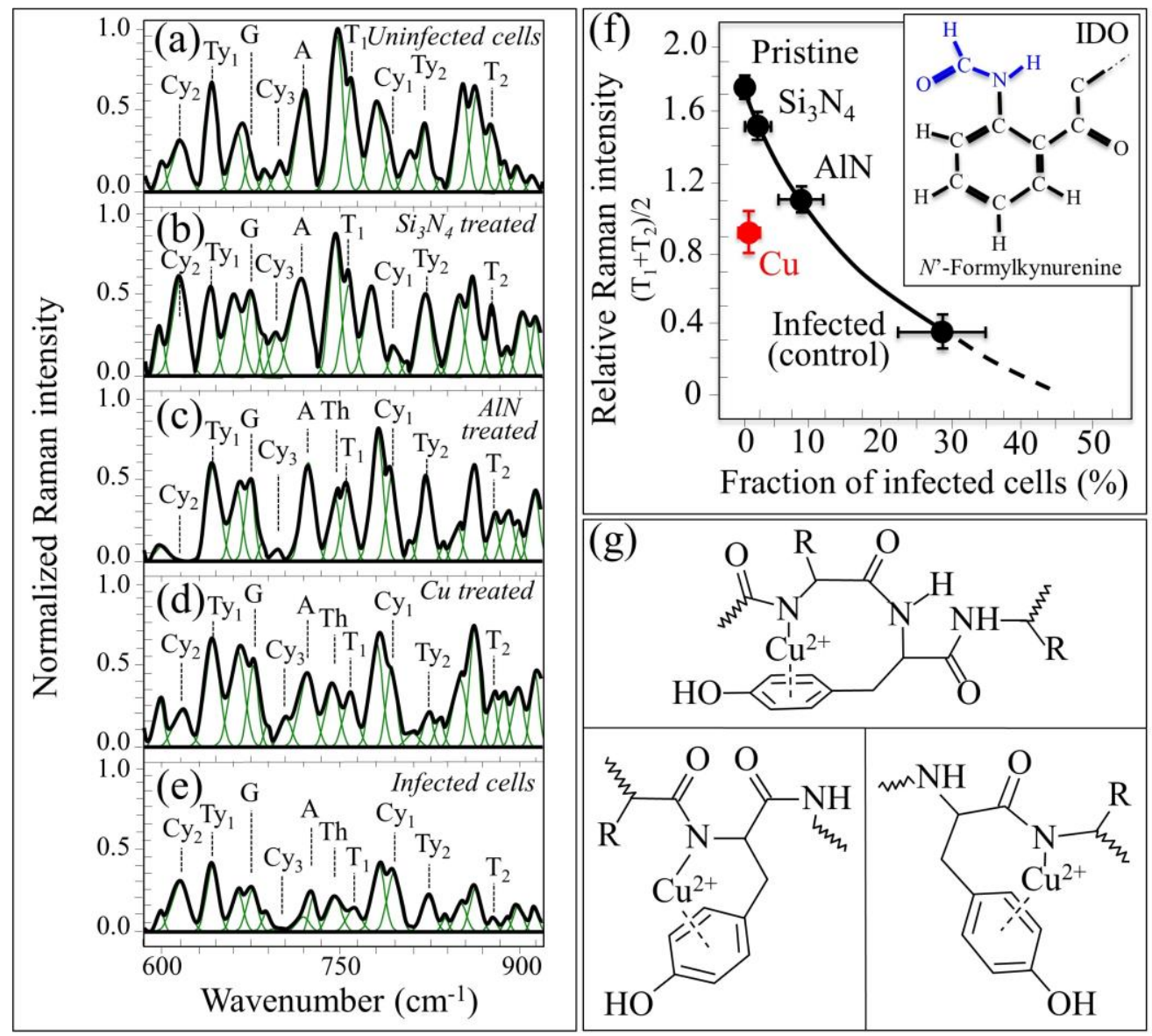

Figure 5. Raman spectra of: (a) uninfected cells (i.e., unexposed to virions), and cells infected with SARS-CoV-2 virions exposed for 10 min to (b) $\mathrm{Si}_{3} \mathrm{~N}_{4}$, (c) $\mathrm{AlN}$, and (d) $\mathrm{Cu}$; in (e), Raman spectrum of cells infected by unexposed virions (negative control). In (f), a plot of the average intensity of the two tryptophan $\mathrm{T}_{1}$ and $\mathrm{T}_{2}$ bands (at 756 and $875 \mathrm{~cm}^{-1}$, respectively) as a function of the fraction of infected cells by virions unexposed and exposed for 10 min to different particles ( $c f$. labels); in the inset, the structure of N'- formylkynurenine, an intermediate in the catabolism of tryptophan upon enzymatic IDO reaction. In $(\mathrm{g})$, three possible conformations of tyrosine-based peptides that can justify the disappearance of ring vibrations in tyrosine ( $\mathrm{Ty}_{2}$ band) upon chelation of $\mathrm{Cu}$ (II) ions.

The Raman signals due to ring-stretching vibrations of adenine, cytosine, guanine, and thymine were found at 725, 795, 680, and $748 \mathrm{~cm}^{-1}$, and are labeled as $\mathrm{A}, \mathrm{Cy}_{1}, \mathrm{G}$, and Th, respectively, in Fig. 5) [29]. These bands were preserved after virus exposure. However, there was an anomaly for lines representative of tyrosine at 642 and $832 \mathrm{~cm}^{-1}$ labeled as $\mathrm{Ty}_{1}$ and $\mathrm{Ty}_{2}$, respectively [30] for cells infected with $\mathrm{Cu}$-exposed virions. The ring-breathing band $\mathrm{Ty}_{2}$ of tyrosine was very weak compared to the other samples ( $c f$. Fig. 5(d) with (b)). Conversely, the C-C bond-related Ty1 signal remained strong. This suggests that the aromatic ring of tyrosine chelated the $\mathrm{Cu}$ ions [31]. This 
explains why only the tyrosine ring-breathing mode was reduced while the $\mathrm{C}-\mathrm{C}$ signal remained unaltered. Three possible $\mathrm{Cu}(\mathrm{II})$ chelating conformations in tyrosine are given in Fig. 5(g) [31,32].

For VeroE6/TMPRSS2 cells exposed to virions treated with AlN (Fig. 5(c)), the tryptophan $\mathrm{T}_{1}$ and $\mathrm{T}_{2}$ bands were preserved, but the bands at 615 and $~ 700 \mathrm{~cm}^{-1}$ due to ring bending in DNA cytosine (labeled as $\mathrm{Cy}_{2}$ and $\mathrm{Cy}_{3}$, respectively, in Fig. 5) almost vanished [29]. Their disappearance is due to either progressive internucleosomal DNA cleavage or from the formation of complexes, and both are related to toxicity $[33,34]$. The loss of the cytosine signals is interpreted as a toxic effect by $\mathrm{Al}$ ions, although it is far less critical than copper. $\mathrm{Al}^{3+}$ interacts with carbonyl $\mathrm{O}$ and/or $\mathrm{N}$ ring donors in nucleotide bases [35,36] and selectively binds to the backbone of the $\mathrm{PO}_{2}$ group and/or to the guanine N-7 site of the G-C base pairs by chelation $[37,38]$.

Unlike exposure of the VeroE6/TMPRSS2 cells to $\mathrm{Cu}$ and AlN supernatants, which resulted in moderate to severe toxicity, $\mathrm{Si}_{3} \mathrm{~N}_{4}$ invoked no modifications of tryptophan, tyrosine, and cytosine. The morphology of the spectrum for the $\mathrm{Si}_{3} \mathrm{~N}_{4}$ viral supernatant closely matched that of the uninfected sham suspension ( $c f$. Figs. 5(a) and (b)).

\section{Discussion}

The persistence of human coronaviruses on common materials (e.g., metal, plastic, paper, and fabric) and touch surfaces (e.g., knobs, handles, railings, tables, and desktops) can contribute to the nosocomial and social spread of disease $[39,40]$. Warnes et al. reported that at room temperature with 30\%-40\% humidity, the pathogenic human coronavirus $229 \mathrm{E}$ (HuCoV-229E) remained infectious in a lung cell model after at least 5 days of persistent viability on a variety of materials, such as Teflon, polyvinyl chloride, ceramic tile, glass, stainless steel, and silicone rubber [3]. These investigators also showed rapid $\mathrm{HuCoV}-229 \mathrm{E}$ inactivation (within a few minutes) for simulated fingertip contamination on $\mathrm{Cu}$ surfaces. $\mathrm{Cu}$ ion release and the generation of reactive oxygen species (ROS) were involved in viral inactivation; and increased contact time with copper and brass surfaces led to greater non-specific fragmentation of viral RNA, indicating irreversible viral inactivation [3]. More recently, Doremalen et al. showed surface stability of both SARS-CoV-1 and SARS-CoV-2 virus on plastic, cardboard, stainless steel, and even $\mathrm{Cu}$ surfaces for $4 \sim 72$ hours after application [41]. While breathable N95-rated masks can capture particulates before they can be inhaled, SARS-CoV-2 virus particles remain active in mask filters for up to 7 days [4]. Contact killing of viruses, such as observed on $\mathrm{Cu}$ surfaces is, therefore, receiving renewed interest as a disease mitigation strategy [17].

The present work is the first to show that compounds capable of endogenous nitrogen-release, such as $\mathrm{Si}_{3} \mathrm{~N}_{4}$ and $\mathrm{AlN}$, can inactivate the SARS-CoV-2 virus at least as effectively as $\mathrm{Cu}$. These results suggest that multiple antiviral mechanisms may be operative, such as RNA fragmentation, and in the case of $\mathrm{Cu}$, direct metal ion toxicity; but while $\mathrm{Cu}$ and $\mathrm{AlN}$ supernatants demonstrated strong and partial cellular lysis, respectively, $\mathrm{Si}_{3} \mathrm{~N}_{4}$ provoked no metabolic alterations. The Raman spectrum of VeroE6/TMPRSS2 cells exposed to the $\mathrm{Si}_{3} \mathrm{~N}_{4}$ viral supernatant was like that of the uninfected sham. These findings indicate that while $\mathrm{Si}_{3} \mathrm{~N}_{4}, \mathrm{Cu}$, and $\mathrm{AlN}$ were all capable of inactivating the SARS-CoV-2 virus, $\mathrm{Si}_{3} \mathrm{~N}_{4}$ was the safest compound for the tested cell model.

These data on SARS-CoV-2 are consistent with a recent investigation that showed rapid 
inactivation of three single-strand RNA viruses (H1N1 (Influenza A/Puerto Rico/8/1934), Feline calicivirus, and Enterovirus (EV-A71) upon exposure to aqueous suspensions of powdered 15 wt. $\% \mathrm{Si}_{3} \mathrm{~N}_{4}$ [16]. The antiviral effect in this prior study was related to the electrical attraction (including "binding competitive" to an envelope glycoprotein hemagglutinin in the case of influenza virus) and viral RNA fragmentation by reactive nitrogen species (RNS). These phenomena are due to the slow and controlled elution of nitrogen from $\mathrm{Si}_{3} \mathrm{~N}_{4}$ 's surface, which forms ammonia $\left(\mathrm{NH}_{3}\right)$ and ammonium $\left(\mathrm{NH}^{4+}\right)$ moieties coupled with the release of free electrons and negatively charged silanols in aqueous solution.

In the context of SARS-CoV-2 viral inactivation, two important aspects of $\mathrm{Si}_{3} \mathrm{~N}_{4}$ 's surface chemistry play fundamental roles: (i) the similarity between the protonated amino groups, $\mathrm{SiOH}-\mathrm{NH}_{3}{ }^{+}$ at the surface of $\mathrm{Si}_{3} \mathrm{~N}_{4}$ and the N-terminal of lysine, $\mathrm{C}-\mathrm{NH}_{3}{ }^{+}$on the virus; and, (ii) the elution of gaseous ammonia due to $\mathrm{Si}_{3} \mathrm{~N}_{4}$ hydrolysis. A schematic representation of the interaction between SARS-CoV-2 and the $\mathrm{Si}_{3} \mathrm{~N}_{4}$ surface is given in Fig. 6 (central panel). The similarity is depicted in the left panel of this figure. It triggers an extremely effective "binding competitive" approach to SARS-CoV-2 inactivation which stems from several successful other examples such as Hepatitis $\mathrm{B}$ [42] and Influenza A [43]. The strong antiviral effect of eluted (gaseous) $\mathrm{NH}_{3}$ is due to its penetration of the virions and its reaction with the RNA backbone. The RNA undergoes alkaline transesterification through the hydrolysis of its phosphodiester bonds [44]. RNA phosphodiester bond cleavage is schematically depicted in the right panel of Fig. 6. The RT-PCR and fluorescence microscopy results of the present study suggest contributions from both mechanisms to the inactivation of SARS-CoV-2, consistent with earlier work [16]. While additional experiments are ongoing to confirm the proposed mechanisms of inactivation, the TCID 50 results shown in Fig. 1 and the RT-PCR data of Fig. 2 for viral RNA harvested from either the supernatant or the $\mathrm{Si}_{3} \mathrm{~N}_{4}$ particles provide important information about these mechanisms. Although $>99 \%$ inactivation was achieved after exposure to $\mathrm{Si}_{3} \mathrm{~N}_{4}$ for 1 min, (Fig. 1(b)), only partial viral RNA fragmentation was observed for the supernatant (Fig. 2(a)) while RNA harvested from the $\mathrm{Si}_{3} \mathrm{~N}_{4}$ particles (Fig. 2(b)) was essentially fully fragmented. This suggests that the mechanism of inactivation for $\mathrm{Si}_{3} \mathrm{~N}_{4}$, as depicted in the left panel of Fig. 6, had successive events of "competitive binding" and ammonia poisoning - a kind of "catch and kill" scenario. The complete RNA fragmentation at 10 min exposure to $\mathrm{Si}_{3} \mathrm{~N}_{4}$ suggests that nitrogen elution is a key process that triggers a cascade of reactions, which result in virus inactivation ( $c f$. right panel in Fig. 6).

Note that the antiviral effectiveness of $\mathrm{Si}_{3} \mathrm{~N}_{4}$ was comparable to $\mathrm{Cu}$ [41]. While $\mathrm{Cu}$ is an essential trace element for human health and an electron donor/acceptor for several key enzymes by altering redox states between $\mathrm{Cu}^{+}$and $\mathrm{Cu}^{2+}$ [45], these properties can also cause cellular damage [17]. Its use as an antiviral agent is limited by allergic dermatitis [46], hypersensitivity [47], and multiorgan dysfunction [48].

In contrast, the safety of $\mathrm{Si}_{3} \mathrm{~N}_{4}$ as a permanently implanted material during spine fusion surgery is well established by experimental and clinical data. These observations are consistent with previous studies for $\mathrm{Si}_{3} \mathrm{~N}_{4}$ spine implants made from the same composition. $\mathrm{Si}_{3} \mathrm{~N}_{4}$ is well known for its capabilities as an industrial material [48]. Load-bearing $\mathrm{Si}_{3} \mathrm{~N}_{4}$ prosthetic hip bearings and spinal fusion implants were initially developed because of the superior strength and toughness of $\mathrm{Si}_{3} \mathrm{~N}_{4}$ [50]. Later studies showed other properties of $\mathrm{Si}_{3} \mathrm{~N}_{4}$ that are favored in designing orthopaedic implants, such as enhanced osteoconductivity [51-54] and bacteriostasis [14,55-60]. Taken together, 
these data suggest that $\mathrm{Si}_{3} \mathrm{~N}_{4}$ 's surface chemistry, previously known to contribute concurrent upregulation of osteogenic activity and prevention of bacterial adhesion and biofilm formation, is also quite effective against viruses. Sintered powders of $\mathrm{Si}_{3} \mathrm{~N}_{4}$ have been incorporated into other materials, such as polymers [61,62], other ceramics [63], and bioglass [64,65] to create composite structures that maintain the index osteogenic and antibacterial properties of monolithic $\mathrm{Si}_{3} \mathrm{~N}_{4}$. Three-dimensional additive deposition of $\mathrm{Si}_{3} \mathrm{~N}_{4}$ could, at least in theory, enable the manufacture of protective surfaces in health care that reduce fomite-mediated transmission of microbial disease [66].
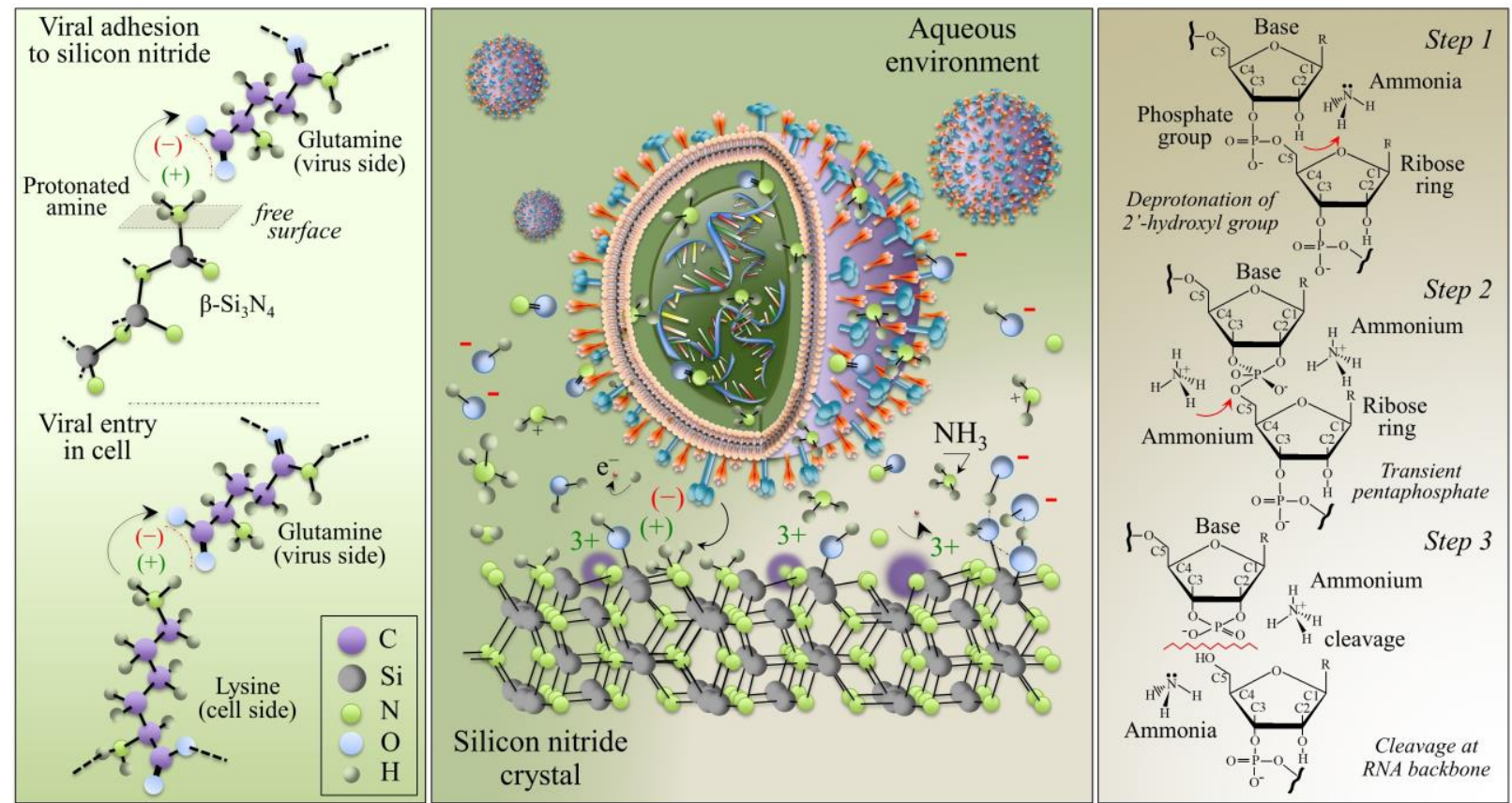

Figure 6. Schematic model illustrating: a chemical and electrical charge similarity between the protonated amine groups, $\mathrm{Si}-\mathrm{NH}_{3}{ }^{+}$, at the surface of $\mathrm{Si}_{3} \mathrm{~N}_{4}$ and the $\mathrm{N}$-terminal of lysine, $\mathrm{C}-\mathrm{NH}_{3}{ }^{+}$ in cells (left panel); and, the interaction of SARS-CoV-2 viruses with the charged molecular species at the surface of $\mathrm{Si}_{3} \mathrm{~N}_{4}$ (specifically, at protonated amines charging plus) and the eluted species $\mathrm{NH}_{3} / \mathrm{NH}_{4}{ }^{+}$(central panel). The eluted $\mathrm{N}$ leaves $3+$ charged vacancies on the solid surface (violet-colored sites), which stem together with negatively charged silanols. The three-step process leading to RNA backbone cleavage by the eluted nitrogen species (namely, deprotonation of 2'-hydroxyl groups, formation of a transient pentaphosphate, and cleavage of the phosphodiester bond in the RNA backbone by alkaline transesterification through hydrolysis) is shown in the right panel. Note that the similarity between the protonated amine and N-terminal of lysine might trigger an extremely effective "binding competitive" mechanism for SARSCoV-2 virion inactivation, while eluted ammonia fatally degrades the virion RNA in a combined "catch and kill" effect.

Incorporation of $\mathrm{Si}_{3} \mathrm{~N}_{4}$ particles into the fabric of personal protective equipment, such as face masks, protective gowns, and surgical drapes could contribute to health workers as well as patient safety. Further studies and testing are necessary to corroborate our findings and to establish the antiviral attributes of $\mathrm{Si}_{3} \mathrm{~N}_{4}$ composites and coatings. 


\section{Conclusions}

In summary, it was shown that $\mathrm{Si}_{3} \mathrm{~N}_{4}$ inactivates the $\mathrm{SARS}-\mathrm{CoV}-2$ virus in a matter of minutes following exposure. Similar results with AlN suggest that the mechanism of action is shared with other nitrogen-based compounds that release trace amounts of surface disinfectants slowly and for the long-term. These data may prove useful in designing products and strategies to mitigate the spread of viral diseases.

\section{Affiliations}

Ceramic Physics Laboratory, Kyoto Institute of Technology (G.P., W.Z., E.M., F.B.); Department of Immunology, Kyoto Prefectural University of Medicine (O.M., G.P., F.B., E.O., M.S.-Y., T.A.); Department of Dental Medicine, Kyoto Prefectural University of Medicine (T.A., E.M., F.B.).

\section{Conflicts of Interest}

The authors declare no conflicts of interest.

\section{References}

[1] Kramer A, Schwebke I, Kampf G. How Long Do Nosocomial Pathogens Persist on Inanimate Surfaces? A Systematic Review. BMC Infect Dis. 2006;6:1-8.

[2] Kampf G, Todt D, Pfaender S, Steinmann E. Persistence of Coronaviruses on Inanimate Surfaces and their Inactivation with Biocidal Agents. J Hosp Infect. 2020;104:246-51.

[3] Warnes SL, Little ZR, Keevil CW. Human Coronavirus 229E Remains Infectious on Common Touch Surface Materials. MBio. 2015;6:1-10.

[4] Chin A, Chu J, Perera M, Hui K, Yen H-L, Chan M, et al. Stability of SARS-CoV-2 in Different Environmental Conditions. Lancet Microbe. 2020;5247:2020.03.15.20036673.

[5] Meyers C, Milici J, Robison R. UVC Radiation as an Effective Disinfectant Method to Inactivate Human Papillomaviruses. PLoS One. 2017;12:1-9.

[6] Vimbela G V., Ngo SM, Fraze C, Yang L, Stout DA. Antibacterial Properties and Toxicity from Metallic Nanomaterials. Int J Nanomedicine. 2017;12:3941-65.

[7] Matsumura Y, Ananthaswamy HN. Toxic Effects of Ultraviolet Radiation on the Skin. Toxicol Appl Pharmacol. 2004;195:298-308.

[8] Smith MW, Romano DR, McEntire BJ, Bal BS. A Single Center Retrospective Clinical Evaluation of Anterior Cervical Discectomy and Fusion Comparing Allograft Spacers to Silicon Nitride Cages. J Spine Surg. 2018;4:349-60.

[9] Ball HT, McEntire BJ, Bal BS. Accelerated Cervical Fusion of Silicon Nitride versus PEEK Spacers: A Comparative Clinical Study. J Spine. 2017;6:1000396.

[10] Arts MP, Wolfs JFC, Corbin TP. Porous Silicon Nitride Spacers versus PEEK Cages for Anterior Cervical Discectomy and Fusion: Clinical and Radiological Results of a Single- Blinded Randomized Controlled Trial. Eur Spine J. 2017;26:2372-9.

[11] Calvert GC, Huffmon III G V, Rambo Jr WM, Smith MW, McEntire BJ, Bal BS. Clinical Outcomes for Anterior Cervical Discectomy and Fusion with Silicon Nitride Spine Cages: A Multicenter Study. J Spine Surg. 2019;5:504-19.

[12] Calvert GC, Huffmon GVBI, Rambo WMJ, Smith MW, McEntire BJ, Bal BS. Clinical 
Outcomes for Lumbar Fusion using Silicon Nitride versus other Biomaterials. J Spine Surg. 2020;6:33-48.

[13] McEntire BJ, Maislin G, Bal BS. Two-Year Results of a Double-Blind Multicenter Randomized Controlled Non-Inferiority Trial of PEEK versus Silicon Nitride Spinal Fusion Cages in Patients with Symptomatic Degenerative Lumbar Disc Disorders. J Spine Surg. 2020; In Press.

[14] Bock RM, Jones EN, Ray DA, Bal BS, Pezzotti G, McEntire BJ. Bacteriostatic Behavior of Surface-Modulated Silicon Nitride in Comparison to Polyetheretherketone and Titanium. J Biomed Mater Res Part A. 2017;105:1521-34.

[15] Pezzotti G. Silicon Nitride: A Bioceramic with a Gift. ACS Appl Mater Interfaces. 2019;11(30):26619-36.

[16] Pezzotti G, Boschetto F, Ogitani E, Fujita Y, Zhu W, Marin E, et al. A Potent Solid-State Bioceramic Inactivator of ssRNA Viruses. Sci Rep. 2020; under review.

[17] Grass G, Rensing C, Solioz M. Metallic Copper as an Antimicrobial Surface. Appl Environ Microbiol. 2011;77:1541-7.

[18] Fukumoto S, Hookabe T, Tsubakino H. Hydrolysis Behavior of Aluminum Nitride in Various Solutions. J Mater Sci. 2000;35:2743-8.

[19] Krnel K, Kosmac T. The Hydrolysis of Aluminum Nitride: A Problem or an Advantage. In: Jiang D, Zeng Y, Singh M, Heinrich J, Editors. Ceram Mater Components Energy Environ Appl. Columbus, OH USA: The American Ceramic Society; 2010. p. 39-46.

[20] McEntire BJ, Lakshminarayanan R, Thirugnanasambandam P, Seitz-Sampson J, Bock R, O'Brien D. Processing and Characterization of Silicon Nitride Bioceramics. Bioceram Dev Appl. 2016;6:1000093.

[21] Matsuyama S, Nao N, Shirato K, Kawase M, Saito S, Takayama I, et al. Enhanced Isolation of SARS-CoV-2 by TMPRSS2- Expressing Cells. Proc Natl Acad Sci USA. 2020;117:70013.

[22] Reed LJ, Muench M. A Simple Method of Estimating Fifty Percent Endpoints. Am J Hyg. 1938;27:493-7.

[23] Balamurugan K, Schaffner W. Copper Homeostasis in Eukaryotes: Teetering on a Tightrope. Biochim Biophys Acta - Mol Cell Res. 2006;1763:737-46.

[24] Zhu G, Zhu X, Fan Q, Wan X. Raman Spectra of Amino Acids and their Aqueous Solutions. Spectrochim Acta - Part A Mol Biomol Spectrosc. 2011;78:1187-95.

[25] De Jesus AJ, Allen TW. The Role of Tryptophan Side Chains in Membrane Protein Anchoring and Hydrophobic Mismatch. Biochim Biophys Acta - Biomembr. isêpi 2013;1828:864-76.

[26] Mellor AL, Munn DH. Tryptophan Catabolism and Regulation of Adaptive Immunity. J Immunol. 2003;170:5809-13.

[27] Fox JM, Sage LK, Huang L, Barber J, Klonowski KD, Mellor AL, et al. Inhibition of Indoleamine 2,3-Dioxygenase Enhances the T-Cell Response to Influenza Virus Infection. J Gen Virol. 2013;94:1451-61.

[28] Okada M, Miura T. Copper(I) Stabilization by Cysteine/Tryptophan Motif in the Extracellular Domain of Ctr4. J Inorg Biochem. 2016;159:45-9.

[29] Otto C, van den Tweel TJJ, de Mul FFM, Greve J. Surface-Enhanced Raman Spectroscopy of DNA Bases. J Raman Spectrosc. 1986;17:289-98.

[30] Li H, Wurrey CJ, Thomas GJ. Cysteine Conformation and Sulfhydryl Interactions in Proteins and Viruses. 2. Normal Coordinate Analysis of the Cysteine Side Chain in Model Compounds. J Am Chem Soc. 1992;114:7463-9.

[31] Peifeng H, Sorensen C, Gross ML. Influences of Peptide Side Chains on the Metal Ion 
Binding Site in Metal Ion-Cationized Peptides: Participation of Aromatic Rings in Metal Chelation. J Am Soc Mass Spectrom. 1995;6:1079-85.

[32] Vandenbossche M, Jimenez M, Dehaese A, Traisnel M, Casetta M. Tyrosine: An Efficient Natural Molecule for Copper Remediation. Green Mater. 2015;3:1-9.

[33] Brauchle E, Thude S, Brucker SY, Schenke-Layland K. Cell Death Stages in Single Apoptotic and Necrotic Cells Monitored by Raman Microspectroscopy. Sci Rep. 2014;4:4698.

[34] Notingher I, Green C, Dyer C, Perkins E, Hopkins N, Lindsay C, et al. Discrimination between Ricin and Sulphur Mustard Toxicity in vitro Using Raman Spectroscopy. J R Soc Interface. 2004;1:79-90.

[35] Harris WR, Berthon G, Day JP, Exley C, Flaten TP, Forbes WF, et al. Speciation of Aluminum in Biological Systems. J Toxicol Environ Health. 1996;48:543-68.

[36] Kanellis VG, dos Remedios CG. A Review of Heavy Metal Cation Binding to Deoxyribonucleic Acids for the Creation of Chemical Sensors. Biophys Rev. Biophysical Reviews; 2018;10:1401-14.

[37] Rao KSJ, Rao BS, Vishnuvardhan D, Prasad KVS. Alteration of Superhelical State of DNA by Aluminium (Al). BBA - Gene Struct Expr. 1993;1172:17-20.

[38] Ahmad R, Naoui M, Neault JF, Diamantoglou S, Tajmir-Riahi HA. An FTIR Spectroscopic Study of Calf-Thymus DNA Complexation with Al(III) and Ga(III) Cations. J Biomol Struct Dyn. 1996;13:795-802.

[39] Otter JA, Yezli S, Salkeld JAG, French GL. Evidence that Contaminated Surfaces Contribute to the Transmission of Hospital Pathogens and an Overview of Strategies to Address Contaminated Surfaces in Hospital Settings. Am J Infect Control. 2013;41:S6.

[40] Otter JA, Yezli S, French GL. The Role of Contaminated Surfaces in the Transmission of Nosocomial Pathogens. In: Borkow G, editor. Use Biocidal Surfaces Reduct Healthc Acquir Infect. Heidelberg New York Dordrecht London: Springer Cham; 2014. p. 1-215.

[41] Doremalen N van, Bushmaker T, Morris DH. Aerosol and Surface Stability of SARS-CoV- 2 as Compared with SARS-CoV-1. N Engl J Med. 2020;Correspond:1-3.

[42] Ye X, Zhou M, He Y, Wan Y, Bai W, Tao S, et al. Efficient Inhibition of Hepatitis B Virus Infection by a PreS1-Binding Peptide. Sci Rep. Nature Publishing Group; 2016;6:1-11.

[43] Yuan S, Chu H, Zhang K, Ye J, Singh K, Kao RYT, et al. A Novel Small-Molecule Compound Disrupts Influenza A Virus PB2 Cap-Binding and Inhibits Viral Replication. J timicrob Chemother. 2016;71:2489-97.

[44] Decrey L, Kazama S, Udert KM, Kohn T. Ammonia as an in-situ Sanitizer: Inactivation Kinetics and Mechanisms of the ssRNA Virus MS2 by $\mathrm{NH}_{3}$. Environ Sci Technol. 2015;49:1060-7.

[45] Karlin KD. Metalloenzymes, Structural Motifs, And Inorganic Models. Science (80- ). 1993;262:1499.

[46] Yoshihisa Y, Shimizu T. Metal Allergy and Systemic Contact Dermatitis: An Overview. Dermatol Res Pract. 2012;2012.

[47] Fage SW, Faurschou A, Thyssen JP. Copper Hypersensitivity. Contact Dermatitis. 2014;71:191-201.

[48] Scholar PG. An Overview of Copper Toxicity Relevance to Public Health. European J Pharm Med Res. 2018;5:232-7.

[49] Riley FL. Silicon Nitride and Related Materials. J Am Ceram Soc. 2000;83:245-65.

[50] Bal BS, Rahaman MN. Orthopedic Applications of Silicon Nitride Ceramics. Acta Biomater. 2012;8:2889-98. 
[51] Pezzotti G, Marin E, Adachi T, Rondinella A, Boschetto F, Zhu W-L, et al. Bioactive Silicon Nitride: A New Therapeutic Material for Osteoarthropathy. Sci Rep. 2017;7:44848.

[52] Pezzotti G, McEntire BJ, Bock RM, Zhu W, Boschetto F, Rondinella A, et al. In Situ Spectroscopic Screening of Osteosarcoma Living Cells on Stoichiometry-Modulated Silicon Nitride Bioceramic Surfaces. ACS Biomater Sci Eng. 2016;2:1121-34.

[53] Pezzotti G, McEntire BJ, Bock R, Boffelli M, Zhu W, Vitale E, et al. Silicon Nitride: A Synthetic Mineral for Vertebrate Biology. Sci Rep. 2016;6:31717.

[54] Pezzotti G, Oba N, Zhu W, Marin E, Rondinella A, Boschetto F, et al. Human Osteoblasts Grow Transitional Si/N Apatite in Quickly Osteointegrated $\mathrm{Si}_{3} \mathrm{~N}_{4}$ Cervical Insert. Acta Biomater. 2017;64:411-20.

[55] Gorth DJ, Puckett S, Ercan B, Webster TJ, Rahaman M, Bal BS. Decreased Bacteria Activity on $\mathrm{Si}_{3} \mathrm{~N}_{4}$ Surfaces Compared with PEEK or Titanium. Int J Nanomedicine. 2012;7:4829-40.

[56] Webster TJ, Patel AA, Rahaman MN, Bal BS. Anti-Infective and Osteointegration Properties of Silicon Nitride, Poly (Ether Ether Ketone), and Titanium Implants. Acta Biomater. 2012;8:4447-54.

[57] Pezzotti G. A Spontaneous Solid-State NO Donor to Fight Antibiotic Resistant Bacteria. Mater Today Chem; 2018;9:80-90.

[58] Pezzotti G, Bock RM, McEntire BJ, Adachi T, Marin E, Boschetto F, et al. In vitro Antibacterial Activity of Oxide and Non-Oxide Bioceramics for Arthroplastic Devices: I. In situ Time-Lapse Raman Spectroscopy. Analyst. 2018;143:3708-21.

[59] Boschetto F, Toyama N, Horiguchi S, Bock RM, McEntire BJ, Adachi T, et al. In vitro Antibacterial Activity of Oxide and Non-Oxide Bioceramics for Arthroplastic Devices: II. In situ Time-Lapse Fourier Transform Infrared Spectroscopy. Analyst. 2018;143:2128-40.

[60] Boschetto F, Adachi, T, Horiguchi S, Fainozzi D, Parmigiani F, Marin E, et al. Monitoring Metabolic Reactions in Staphylococcus epidermidis Exposed to Silicon Nitride using in situ Time-Lapse Raman Spectroscopy. J Biomed Opt. 2018;23:1-10.

[61] Zanocco M, Marin E, Boschetto F, Adachi T, Yamamoto T, Kanamura N, et al. Surface Functionalization of Polyethylene by Silicon Nitride Laser Cladding. Appl Sci. 2020;10:2612.

[62] Pezzotti G, Marin E, Adachi T, Lerussi F, Rondinella A, Boschetto F, et al. Incorporating $\mathrm{Si}_{3} \mathrm{~N}_{4}$ into PEEK to Produce Antibacterial, Osteoconductive, and Radiolucent Spinal Implants. Macromol Biosci. 2018;1080033.

[63] Marin E, Zanocco M, Boschetto F, Santini M, Zhu W, Adachi T, et al. Silicon Nitride Laser Cladding: A Feasible Technique to Improve the Biological Response of Zirconia. Mater Des. Elsevier Ltd; 2020;108649.

[64] Marin E, Adachi T, Boschetto F, Zanocco M, Rondinella A, Zhu W, et al. Biological Response of Human Osteosarcoma Cells to $\mathrm{Si}_{3} \mathrm{~N}_{4}$-Doped Bioglasses. Mater Des. 2018;159:7989.

[65] Marin E, Adachi T, Zanocco M, Boschetto F, Rondinella A, Zhu W, et al. Enhanced Bioactivity of $\mathrm{Si}_{3} \mathrm{~N}_{4}$ through Trench-Patterning and Back-Filling with Bioglass ${ }^{\circledR}$. Mater Sci Eng C. 2019;106:110278.

[66] Zanocco M, Boschetto F, Zhu W, Marin E, McEntire BJ, Bal BS, et al. 3D-Additive Deposition of an Antibacterial and Osteogenic Silicon Nitride Coating on Orthopaedic Titanium Substrate. J Mech Behav Biomed Mater. 2020;103:103557. 